\title{
Jacques Barsotti, Jean Cancel, Christian Robert (eds): Guide pratique de traumatologie 6ème édition
}

\author{
Elsevier Masson, Issy-lès-Moulineaux, France, 2010, 340 pp, 3 nbr. Figs., 69,00 €, \\ ISBN 978-2-294-70300
}

Pierre Kehr

Received: 24 November 2011 / Accepted: 26 November 2011/Published online: 11 December 2011

(c) Springer-Verlag 2011

This sixth edition remains a must for the young surgeons in formation and beyond that, for any doctor confronted with the traumatisms of the locomotor apparatus, in particular for the first doctor who approaches the traumatized patient and must at the same time make the good decisions quickly and give to patient and with his entourage good information.

Indeed each chapter is built on the same model, designed very well: (1) what you know already, (2) what we can specify, and (3) some data to inform the patient and his doctor.

Sixty-one chapters make it possible to treat all traumatology since that of the cervical spine, of the traumatisms of the thoracic member, the traumatisms of the thoracolombal spine, the sacrum and the coccyx, to finish by the traumatisms of the pelvic member.

The various chapters are written in a clear way and are illustrated by very precise diagrams.

It is about an excellent handbook that should be in the library of all the young surgeons, urgentists, and general doctors so often confronted with the first assumption of responsibility of traumatized of circulation or the sport.

Cette sixième édition reste un must pour les jeunes chirurgiens en formation et au delà, pour tout médecin confronté aux traumatismes de l'appareil locomoteur, en particulier pour le premier médecin qui s'approche du blessé et doit à la fois prendre rapidement les bonnes décisions et donner au blessé et à son entourage les bonnes informations.

En effet chaque chapitre est construit sur le même modèle, très bien conçu : $1^{\circ}$ ) Ce que vous savez déjà, $2^{\circ}$ ) Ce que nous pouvons préciser, and $3^{\circ}$ ) Quelques chiffres pour informer le malade et son médecin. 61 chapitres permettent de traiter toute la traumatologie depuis celle du rachis cervical, des traumatismes du membre thoracique, des traumatismes du rachis thoraco-lombaire, du sacrum et du coccyx, pour terminer par les traumatismes du membre pelvien.

Les différents chapitres sont écrits de façon claire et sont illustrés par des schémas très précis.

Il s'agit d'un excellent manuel qui devrait se trouver dans la bibliothèque de tous les jeunes chirurgiens, urgentistes, médecins généralistes si souvent confrontés à la première prise en charge des traumatisés de la circulation ou du sport.

\section{Pierre Kehr}

Conflict of interest No funds were received in support of this study.
P. Kehr $(\bowtie)$

Strasbourg, France

e-mail: kehrpier@aol.com 